\title{
British Thermal Unit 39 Degrees Fahrenheit
}

National Cancer Institute

\section{Source}

National Cancer Institute. British Thermal Unit 39 Degrees Fahrenheit. NCI Thesaurus.

Code C69150.

A non-SI unit of energy equal to the amount of heat required to raise the temperature of one pound avoirdupois of air-free water by one degree Fahrenheit (from 38.5 to 39.5 degrees) at a constant pressure of one atmosphere. The British thermal unit at 39 degrees Fahrenheit is based on the definition of the calorie value of water at its maximum density (4 degrees Celsius), and is equal to approximately $1.05967 \mathrm{~kJ}$. 